\title{
A nightmare of AIDS
}

SIR - In your timely article on acquired immune deficiency syndrome (AIDS) (Nature 2 June, p.377) you pertinently pointed out its possible relation to human T-cell leukaemia-lymphoma virus (HTLV). This is an apparently infectious human oncogenic retrovirus, recently found independently in Caribbean areas as well as in the United States and Israel on the one hand and among the south-western Japanese on the other hand. The various isolates proved to be similar in their molecular properties (Nature 302, 567; 1983). The Japanese virus strain, called the adult T-cell leukaemia virus (ATLV), can be activated in vitro from virus-free, peripheral-blood mononuclear cells of adult patients suffering from leukaemia!, and the specific virus antibody was found in 25 per cent of the healthy population of the area where ATLV is indigenous. Moreover, the virus could be produced by activation in vitro from the blood cells of apparently healthy people ${ }^{1,2}$.

HTLV is similar to mouse Moloney leukaemia virus ${ }^{3}$ in its chronically oncogenic nature, and may be classified as a weak oncogenic retrovirus which does not contain an oncogene but may be integrated in the vicinity of a cellular oncogene of the host chromosome to cause leukaemia at a later stage of life. It was also shown in this connection $^{3}$ that the inactive virus genome integrated into the chromosome in an artificially-produced chronically leukaemic substrain of mouse could be activated, through demethylation, when the Moloney leukaemia provirus DNA from liver of the non-leukaemic mouse of this substrain was cloned in bacteria ${ }^{3}$. In the past we have raised the question as to whether this last piece of evidence is relevant to the problem of safety in recombinant DNA work ${ }^{4,5}$. While preparing the article $^{4}$, I had a chance to point out to the Recombinant DNA Monitoring Committee in Australia that, contrary to its conviction, this kind of leukaemia retrovirus should be relevant to our safety concern because it might be related to the ATLV then already known to science for nearly a year. The Australian Committee enquired about the problem of some overseas authorities on recombinant DNA, including GMAG in the United Kingdom. Apparently the overseas bodies reassured it that the problem might be dismissed without the need for any experimentation. In fact, you reported (Nature 302, 465; 1983) that most GMAG members might not be up to date in their knowledge of the subject on the one hand, but also that GMAG should be phased out on the other hand, because the concern about safety of recombinant DNA is also becoming out of date.

I now feel that the concern and uncertainty about AIDS at one end and the smug complacency about the safety of the recombinant DNA work involving oncogenes and retroviruses at the other end are not logically consistent attitudes to be taken by the same scientific community, especially when there is a suggestion that the two ends may be linked by a common agent, the leukaemia retrovirus. May 1 quote from the two articles in Nature which I referred to above? (Italics are mine.)

"The popular nightmare, that genetic manipulation might, even by accident, create especially virulent microorganisms, was never more than a scare" (7 April p.465; and ". . . . the unexpected appearance in the past few years. of this bizarre disease [AIDS] has provoked a sense of nightmare"' (2 June, p.377).

\section{CSIRO Molecular and Cellular} A. SiBATANI

\section{Biology Unit.}

North Ryde (Sydney),

NSW 2113, Australia

1. Hinuma, Y. et al. Gann 73, 341-344 (1982).

2. Gotoh, Y., Sugamura K. \& Hinuma, Y. Proc. natn. Acad. Sci. U.S.A. 79, 4780-4782 (1982).

3. Harbers, K., Schnieke, A., Stuhlmann, H., Jăhner, D. \& Jaenisch, R. Proc. natn. Acad. Sci. U.S.A. 78, 7609-7613 (1981).

4. Bartels, D., Naora, H. \& Sibatani, A. Trends biochem. Sci. 8, 78-80 (1983).

5. Barleis, D. Search (Sydney) 14, 89-92 (1983).

6. Ada, G.L. Search (Sydney) 14, 92 (1983).

\section{To be or not to be}

SIR - In his interesting commentary on consciousness (Nature 3 May, p. 11), Professor Crook touches on the problem of defining living beings as distinct from manmade things. He correctly states that "all organisms share a self-referential cybernetic physiological system evolved to ensure self-maintenance at least until reproduction". This is a rather abstruse way of saying that "all organisms not only exist but also want to exist, that is, they have a self-directed will".

The operative cause for this is obvious: the subjective correlate of an assault on existence is pain, while the subjective correlate of the removal of such an assault is pleasure.

The ultimate cause belongs to the domain of metaphysics. As I stated before (Nature 228, 888; 1970) the problem appears insoluble, because we have known since Kant that the categories of being cannot be used to define Being as such, or, to put it another way, the will as "Ding an sich" cannot will anything but itself. Its choice is limited to the alternative: to be or not to be.

Here religion can transcend metaphysics by stating that: "All matter longs for life, all life longs for (higher) consciousness, all consciousness longs for God".

Laboratoire Central,

S.V. VAECK

Administration de l'Industrie,

Ministère des Affaires Economiques, Brussels, Belgium

\section{Decision-making}

SIR - How to achieve "truly democratic" methods of choice between alternatives, a question raised by Professor R.M. May', transcends purely local problems.

Other examples of dissatisfaction with the performance of those whose business it is to take decisions, from the single voter to ministers or heads of state, are easy to find. There are two on the same page of a later issue of your journal ${ }^{2}$, an editorial in a parallel publication ${ }^{3}$, another in a more specialized contemporary ${ }^{4}$ and so on.

Amongst many known reasons for failures to decide well, or to decide at all, are: failure to define the problem, failure to decide how to choose those who are to decide, confusion between the roles of the expert and the legislator, basic limitations in human mentation such as the lack of transitivity in statements of preference. Problems will continue to arise so long as decisions are reported solely in terms of their outcome, and the processes leading to them remain unexamined. Examples from many different fields show high correlations between final judgements. The majority of studies stop there, and so fail to show that very different strategies may have been used by individuals who "agree". They may use different sources of information, weight the same sources differently or combine them in different ways. The danger lies in their assumption that their strategies were identical because their overall judgements were in agreement. When they fail to agree on subsequent occasions, there will certainly be surprise and there may be disappointment, incomprehension or outright conflict.

It is not enough to show high overall agreement between managers and unions 5 or between medical diagnosticians ${ }^{6}$ on a particular set of instances. To predict the extent of agreement in the future, and (if agreement is considered to be desirable) to increase it, it is essential to describe explicitly the judgemental strategies of those whose decisions carry weight in any size of community. Fortunately, a large body of research addresses such problems ${ }^{7-9}$, all tending to show that cognitive analysis is more likely to lead to happier committees and better decisions than game theory, second-guessing confrontation or agendaless summit meetings.

C.R.B. JOYCE

Beim Lindenbaum 15,

4123 Allschwil, Switzerland

May, R.M. Nature 303, 16-17 (1983).

Nature 303, 270 (1983)

Science 220, 13 May (1983)

Br. med. J. 286, 1079-1081 (1983)

Balke, W.M., Hammond, K.R. \& Meyer, (i.D. Admin. Sci. Q. 18. 311-327 (1973)

6. Fisch, H.-U., Hammond, K.R., Joyec, C.R.B. \& O'Reilly, M. Br. J. Psychiat. 138, 100-109 (1981).

Hogarth, R.M. The Psychology of Decision (Wiley, Chichester, 1980).

8. Hammond, K.R., Meclelland, (i.H. \& Mumpower, I. Human Judgment and Decision Making (Pratger, New York, 1980).

9. Hammond, K.K. \& Joyce, C.R.B. in Drug Monitoring (eds (iross \& Inman) (Academic, l.ondon, 1977). 